\title{
AN ERROR ANALYSIS OF USING PUNCTUATION MADE BY STUDENTS IN DESCRIPTIVE TEXT AT THE SECOND YEAR STUDENTS OF SMPN 3 WERA IN ACADEMIC YEAR 2017/2018
}

\author{
Sarif Husada' ${ }^{1}$ Hidayati $^{2}$, Humaira ${ }^{3}$ \\ 1,2,3Pendidikan Bahasa Inggris, Universitas Muhammadiyah Mataram, sarifhusada@gmail.com
}

\begin{tabular}{l} 
INFO ARTIKEL \\
Riwayat Artikel: \\
Diterima: $03-02-2018$ \\
Disetujui: $10-03-2018$ \\
\hline
\end{tabular}

Key Word:

Error Analysis

Punctuation

\begin{abstract}
Abstract: Punctuation is set of mark used in writing to clarify the meaning and to separate the sentences, word and part of word. The using of punctuation is considered as the important aspect in productive writing skill. Therefore, it was important students to master it. The purpose of this study is to find out the students' errors in using punctuation in descriptive text made by second year students of SMPN 3 Wera in academic year 2017/018. The subject of this study is students' from second year in SMPN 3 Wera. The mixed method qualitative and quantitative used in this study. The study applied purposive sampling. The researcher took 21 students as a sample at a class. In collecting the data, this study used observation and writing test as the research instrument then followed by analyzing the data using formula. This study found that were two kinds of punctuation and two types of errors (period, comma, omission and addition) which classified, there are 42 errors that occurs made by the students which consist of 11 or $26 \%$ students made errors in period, 15 or $36 \%$ errors of comma, 4 or $10 \%$ errors of addition and 12 or $28 \%$ errors of omission. The dominant errors showed by the students in form of comma which 15 or $36 \%$ errors. Based on the result of this study, the researcher concluded that the students still made many errors in using punctuation.
\end{abstract}

\section{A. BACKGROUND OF THE STUDY}

In language learning process, there are four skills that must be mastered by students. Those skills are listening, reading, writing and speaking all of the skills are important for students to mastered, especially at writing. Writing is the most difficult skill in language. Writing is the putting down the graphic symbol in sentence or paragraph and to delivers some meaning to the reader. In writing, students can express their feeling, emotion and desire they want to write. When students want to write, they must know about conventional aspect in writing like grammar, vocabulary, structure, and punctuation. In globalization era, people used their writing to show their idea, as a newspaper which used to informing the reader about what they have done through writing.

Punctuation is the sign on writing which make meaning of the sentences became clear and make the reader easy to understand about the meaning or massages that the writer wants to deliver. Punctuation is standard set of marks which used in written to clarify meaning and to separated sentences, words, and parts of words (Intan, 2015: 1).

Based on the information obtained from the English teacher at SMPN 3 Wera, there are large numbers of students did not pay attention, carelessness in use punctuation when they write. The students had difficulties to differentiate kinds of punctuation and where they put the punctuation when they write a paragraph in descriptive text. It is because they did not pay attention and carelessness about the using of punctuation.

Related to this study, there were previous studies that have been conducted by some researchers, they are: First, the study was conducted by Lia Rahmawati (2014) with entitled "Error Analysis of Using Punctuation Made by Students in Writing II Class (A Descriptive Study of the Third Semester Students of the English Department of STAIN Salatiga)". The researcher found that the error kinds made by student are period, comma, question mark, quotation mark, omission and exclamation point.

Second, the study was conducted by Titik Nurhayati (2013) with entitle" Error Analysis of Using Punctuation in English Text (Conducted to students at the Semester Six of English Department)". The researcher found that comma is most common error made by the English Department student during the sixth semester 2010-2011.Carelessness and a lack of high personal standard of excellence must be the basic cause for the students' error.

Third, was conducted by Meta Kartika Wati (2014) with entitle "Errors Made by the Third Semester Students at IAIN Tulungagung in Using Punctuation Marks in Writing Essay". The results showed that there are seven kinds of punctuation marks (comma, period, semicolon, colon, 
apostrophe, question mark, and exclamation mark) which are classified into three types of errors made by the students; consists of error of omission, addition, and misformation.

\section{B. RESEARCH METHOD}

In this research, the researcher used mixed method to analyze the data. According to Creswell in (Sugiyono, 2012: 401) stated that a mixed method design is useful when either the quantitative or qualitative approach by itself is inadequate to best understand a research problem or the strengths of both quantitative and qualitative research can provide the best understanding.

The data were collected by using observation and writing test to take the data. Location of this research is at SMPN 3 Wera with the respondents of this research are students at second grade (a) class where the respondents consist of 21 students. The result of the students score errors percentage was count by using this formula:

$$
P=\frac{F}{N} \mathrm{X} 100 \%
$$

In which:

$p$ : Percentage (students' mastery)

$f$ : Frequency (students' score)

$n$ : Total errors of respondents (students)

Gass and Selinker (2008; 103).

\section{FINDING}

TABLE 1

Percentage of Punctuation Error in English Text

\begin{tabular}{|c|l|c|c|}
\hline No & $\begin{array}{c}\text { Punctuation } \\
\text { Errors }\end{array}$ & $\begin{array}{c}\text { Frequency of } \\
\text { Errors Made by } \\
\text { 21 Students }\end{array}$ & Percentage \\
\hline 1 & Period & 11 & $26 \%$ \\
\hline 2 & Comma & 15 & $36 \%$ \\
\hline 3 & Addition & 4 & $10 \%$ \\
\hline 4 & Omission & 12 & $28 \%$ \\
\hline \multicolumn{2}{r|}{ Total } & $\mathbf{4 2}$ & $\mathbf{1 0 0 \%}$ \\
\hline
\end{tabular}

The result of table above there are 42 various kinds of errors found by the researcher. Where the most dominant error students made is comma 15 or $36 \%$.

\section{DISCUSSION}

\section{Period}

Omission of period means that a complete thought of a sentence ended without a period. The absence of period in the end of sentence made the sentence unclear. The total errors of period made by the students were 11 or $26 \%$. For examples of omission done by the students in period as follow:

1. a. Student's answer: She is not tall but not short she has curly hair and black (A).

b. Correct sentence: She is not tall but not short. She has curly hair and black.
2. a. Student's answer: The name of my place is snake island snake island is my favorite place in my village (N S).

b. Correct sentence: The name of my place is snake island snake. Island is my favorite place in my village.

In sentence above, a period did not used at the suitable placed in a sentence. At the both example: Period did not used to end the sentence and start new sentence.

\section{Addition}

Errors of addition means that the errors that are characterized by the presence of item that must not appear in a well-formed sentence. Contrary with the omission with the total errors made by the students' were 4 or $10 \%$. For example of addition done by the students as follow:

1. a. Student's answer: It so small with with only chair and table nothing else (N)

$b$. Correct sentence: It so small with only chair and table nothing else.

2. a. Student's answer: Snake island just_I in Bima city (NS).

b. Correct sentence: Snake Island just in Bima city.

In the sentence above, words (with $+\boldsymbol{I})$ in two examples was added in a sentence, for avoiding the wrong structure in a sentence. The researcher was correct the wrong sentence.

\section{0mission}

Errors of omission were indicated by the absence of the item that actually needed in well-formed sentence. So in this type, an item or more that should appear in a well-formed sentence is absence or missed. The students' made errors in omission were 12 or $28 \%$. For the example of omission made by the students as follow:

1. a. Student's answer: Morning my mother always wake up first time than me (DDP).

b. Correct sentence: In the morning my mother always wake up first time than me.

2. a. Student's answer: I have a teacher his name Arbianto (FI).

b. Correct sentence: I have a teacher his name is Arbianto.

In the sentence above, the students omit of preposition and to be in a sentence. Omit preposition and to $\boldsymbol{b e}$ in a sentence will make the meaning of the sentences unclear, for the effect! The reader confuse about the meaning of the sentence.

\section{Comma}

The presence of comma that should not appear in a sentence often made different meaning to the sentence itself. The students' made errors in used comma were 15 or $36 \%$. For example the sentence has done by the student as follow: 
1. a. Student's answer: he always wear black shirt,(S A).

b. Correct sentence: he always wear black shirt.

2. a. Student's answer: My school is my favorite place after my home $\mathbf{L}(S S)$.

$b$. Correct sentence: My school is my favorite place after my home.

In the sentences above the students had similar mistake in used comma in sentence; student used wrong punctuation at the end of sentence. In addition a student doing error in addition word and apostrophe of punctuation as follow:

1. a. Every home in my village have manggo's three ( $T H$ )

b. Every home in my village have mango three.

\section{E. CONCLUSSION AND SUGGESTION}

\section{Conclussion}

Based on the finding above, the researcher can concluded that the students made errors in using punctuation in descriptive text, total errors made by the students are 42 errors. The types of punctuation errors made by the students in writing descriptive text were errors of comma with a total of 15 or $36 \%$ and the other is 12 or $28 \%$ in using omission, 4 or $10 \%$ errors of addition and 11 or $26 \%$ error of period. The most error made by the students is comma with percentage 15 or $36 \%$.

\section{Suggestions}

\section{a. For the teachers}

The teachers must pay attention to the students in using punctuation because based on the results; it is found that many errors especially in placing comma, punctuations are often happen in writing. Therefore, the teachers should make the correction and evaluation to the errors of students.

b. For the students

Based on the findings above, it can be said that the students still have some difficulties in placing punctuation. Therefore, they should pay more attention especially punctuation in the way using comma as it becomes an aspect of most dominant error they made.

c. For the researchers

The researcher suggests the next researchers of the similar area, to analyze more deeply about punctuation in the other academic writing, thus they can find more various type of errors on the use of punctuation

\section{ACKNOWLEDGEMENT}

The writer would like to thanks to Hidayati, M.Hum as first consultant and Humaira, M.Pd as second consultant that always give guidance, advising, and motivation to the researcher until this research has done well. Then, the researcher would like to say thank's for Irwandi, M.pd and Rima rahmania, M. Pd as my examiner that has given some correction and revision in researcher thesis.

\section{REFERENCES}

Asayeh N. W. \& Kumar, P. I. P. 2016. A Study On The Difficulties Faced By Libyan University Students In Using Punctuation Marks In English Writing. English Language and Literature (RJELAL): Vol.4. p, 60-63.

Aziz S. S. 2011. Analysis of Errors in Paragraph Writing in English by Second Year. Geography \& History Students at University of Baghdad. Vol. 22. p, 371-387.

H., Burt M., and Krashen S. 1982. Language Two. New York: Oxford University Press.

Harsyaf, (2009). Teaching Writing. Supplement Module MGMPBermutu.

Jefferson \& Smith, W. 2008. Technical Writing for Success (3rd Edition). Canada: South-Western Cengage Learning by Nelson Education, Ltd.

Kane. T,S 1988. The Oxford Essential Guide to Writing. New York: Oxford University Press, Inc.

Khan B. E \& Khan Y. M. 2016. Punctuation Errors made by the Learners of Intermediate Level at Punjab Group of Colleges; An Error Analysis. Department of English Language and Literature, Chenab College of Advance Studies, Mianwali Vol 1. p,26-29.

Kuntjojo. 2009. Metodelogi Penelitian. Universitas Nusantara PGRI Kediri.

Lee, J.F \& Vanpatten, B. (1995). Making Communicative Language Teaching. Happen. USA: McGraw Hill.

McCaskill M. K. 1990. Grammar, Punctuation, and Capitalization. Washington: National Aeronautics and Space Administration Office of Management.

Nanda R. P., Inayah N. \& Gani S. A. 2016. Students' Writing Errors in an Efl Classroom. Syiah Kuala University, Banda Aceh, Indonesia. Vol 1. p, 229-236.

Nurhayati T. 2013. Error Analysis of Using Punctuation in English Text. Universitas Negeri Gorontalo: Unpublished.

Rahmawati L. 2014. Error Analysis Of Using Punctuation Made By Students In Writing II Class. Salatiga: (STAIN) Salatiga: Unpublished.

Sapkota, A. 2012. Developing Students' Writing Skill through Peer and Teacher Correction: An Action Research. Nepal English Language Teachers' Association, NELTA, Vol. 17. p, 70-82.

Siswoyo. 2016. Students' Error in Using Simple Present Tense Mastery. English Education: Tadris Bahasa Inggris: STKIP Muhammadiyah Pringsewu Lampung. Vol 9. p, 461-479.

Siti, M. 2000. A Descriptive Study on Students' Ability to Use Punctuation in Writing. Jember: Jember University: Unpublished.

Straus, J 2008. The Blue Book of Grammar and Punctuation (8 $8^{\text {th }}$ Edition). San Francisco: Jossey-Bass.

Sugiyono. 2016. Metode Penelitian Pendidikan Pendekatan Kuantitative, Kualitative, and R\&D. Bandung: Alfabeta. 
Urquhart V. and Mclver M, (2005). Teaching Writing in the Content Areas. Association for Supervision and Curriculum Development.

Wati M. K. 2014. Errors Made by The Third Semester Students at Iain Tulunguagung in Using Punctuation Marks In Writing Essay. Tulungagung: (IAIN) Tulungagung: Unpublished.

Zemach D. E. \& Rumisek L. A. 2006. Academic Writing from Paragraph to Essay. Macmillan.

\section{The Researcher Profile}

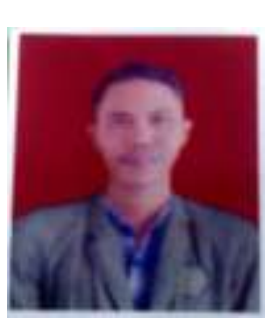

The writer is "sarif Husada". Was born on hidirasa, 19 april 1997. The writer is the second children of three people. Elementary School was began from SDN Inpres Hidirasa on years 20032007. After that, was continued at SMPN 1 Wera of years 2007-2010 and the last at SMAN 1 Wera of years 2010-2013. Then, the researcher was continued at Muhammadiyah University of Mataram in English Education Program FKIP UM Mataram on 2013. Suggestion and criticism or the improvement of this research that has connection with my journal you can be sent it via e-mail in : sarifhusada@gmail.com. 